\title{
QUAKERISM: A QUEST FOR PEACE IN THE ROAD FROM ELEPHANT PASS
}

\author{
Badri Prasad Pokharel* \\ Paras Adhikari
}

\begin{abstract}
The $20^{\text {th }}$ century ended very cruelly in different parts of the world with huge mass of massacres, blood shedding and terrorism which subsequently deteriorate human mind and people who were destined to live in terror, skepticism, and ultimately lack of belief not only in others but in self too. The intensive integration of sustainable peace has been preoccupied, but pragmatically such words remain in rhetoric. Quakerism with the inception of Quakers, a group of friends aligned with positive thinking for the conflict hit society, has embarked the contemporary war ridden society for human betterments, equality, progress and ultimately belief along with the inclination of happy and prosperous meme. Nihal de Silva, a Sri Lankan novelist best known for writing about the civil war that panicked the land for more than three decades has been remembered for bringing the trauma and anticipation of pacification in his works. His best and ever known novel The Road from Elephant Pass is analyzed and interpreted as a commencement of human betterment and sustainable peace in the long war ridden peninsula.
\end{abstract}

Key words: Quaker, pacification, human betterment, equilibrium, inception, panic.

\section{INTRODUCTION AND OBJECTIVE}

As peace and security are two ardent desires of human beings, conflict and violence have also become integral parts of human society. Obviously working for peace and security leads one to work against conflict, violence and insecurity with some ethical values. Studies on peace has become an interdisciplinary issue evolving from the pacifist philosophy that war and conflict have been very bad and devastating. In the same way, peace is compulsory as well as a complex goal to attain in many parts of the world. To attain peace for the well being of human society in the

* Dr. Pokharel is a Lecturer, Saraswoti Campus, Lainchaur, TU, and Mr. Adhikari is freelance writer affiliated with academic institutions. 
twenty first century, the war ridden era, non violence means of resistance and conflict resolution enhance some aspects to ultimate elimination of war and to sustainable peace. The war ridden society is badly devastated with the missiles of lethal weapons as well as post conflict pathos which even the international community has broadly illuminated the pacification of internal and external antagonism. The events that invite catastrophes in the world in the twentieth and twenty first century have not only led the peace advocates to concentrate on final solutions for attaining sustainable peace and security in the society but also enhanced some missions both socially and academically in the Western world i.e. European countries and America in order to investigate alternative permanent remedies to solve the problems. This study focuses on the importance of Quakerism, a mission initiated four hundred years ago by George Fox in Britain to pacify warring people's regression towards an idealistic society which every common denizen expects to have in order to live life. To meet this mission, this article analyzes a Sri Lankan novelist, Nihal De Silva's The Road from Elephant Pass, a novel written about a Sinhalese soldier and a Tamil rebel , two antagonists who are on the way to ultimate resurrection of attaining solution - saving themselves and others as well as illuminating solace in the war ridden peninsula. The principal goal of this study is to show the importance of everlasting peace with preventing the causes of war, bring an ultimate solution and promote the value of peace across the globe.

\section{THEORICAL REVIEW}

\section{Quakerism: a Doctrine for Peace}

Quakerism enloaded with some important testimonies like truth, equality, peace, simplicity, ideal community, fair creed and theology, common ground and finally humanism which is aloof from any kinds of virtual discrimination. Islam (2013), Assistant Professor at Department of Peace and Conflict in University of Dhaka, asserts;

Pacifism is a founding block of Quakerism. The cornerstone of pacifism is that all war is always wrong and should never be resorted to whatever the consequences of abstaining from fighting and the assumption that war is always irrational and inhuman way to solve disputes".(p.138).

Pacifism, therefore, as a basic doctrine of Quakerism has been an important and effective principle of disarming the armed struggle and a way of establishing peace in the conflict-hit zones in the world. 
The evolutionary potential of Quakerism combines social fairness, ecological integrity, a sustainable economy and ultimately a pacifying dimension on warring phenomena into a single focus of wellbeing for human communities and earth's whole commonwealth life. Primarily, the concept of Quakerism based on the teaching of Jesus Christ was coined by George Fox emphasizing on the settlement of peace and harmony in the warring society and not engaging fighting. Quaker pacifists believed war as evil or morally wrong. The main motto of this doctrine is "not to fighting, but suffering in order to bring spiritual reforms" (p.139). It could bring the antagonistic groups into peaceful and harmonious relationship so that they could pursue a healthy life.

In the beginning, it was taken as a part of Christianity, later it challenged the political and warfare supporting role the church was propagating in the war-ridden society. Likewise, philosophers, thinkers and researchers from different walks of life and academic fields showered with their positive views on world peace. It was taken as a movement to discard war and conflict and enhance peace and harmony in the society. Elaborating this argument Boulding (2002) states;

The movement goes back a long time and it inherits a long tradition of philosophical, historical, and literary studies of war and peace and a classical literature in many societies in the study of international law and political philosophy. Thinkers such as Erasmus, Grotius, Kant, William Penn, and so on represent a long history of human thoughts and concern about the problems of war and peace. (p.140)

The intellectual and innovative background they were pursuing was actually very legitimate slogan for peace in Europe and later other parts of the world. The Christian peace as supposed in the beginning was being changed into human relationship or humanist movement or into one related to entire humanity.

Philosophers like Mitchell and Boulding took this movement as human betterment and pacification of the warring communities. They brought this idea to talk about the positive scenarios of social and political development. Though it is used in many non-Quaker contexts, the idea of human betterment, "came into the socio-economic dialogue from this Quaker source. It is another Quaker meme" (Helmuth, 2014, p. 3). Quakerism has become a movement to soothe the rebellion into pacified norms. Besides, it 
appeals for perfection of doing the works as the Quakers are still considered perfectionists. They believe "life without sin could be lived on earth and they set about rather deliberately to organize a society to do this. It was this aspect of Quakerism which so shocked it more pessimistic contemporaries" (Boulding, 2002, p. 9). It is the lifestyle one chooses for himself or herself, that makes it worth living even in conflict hit areas.

Besides, Collony (2013) argues Quakerism as constructive change which would occur across four dimensions i.e. personal, relational, structural and cultural to make peace sustainable for a long time for the transformation of war. The actual Quakers can "contribute towards the constructive and peaceful resolution of conflict" (p.i). Its motto reminisces the war mongers the inception of peaceful propagation.

John Bellers, a veteran of Quakerism elucidates human betterment for sustainable peace in the war-threatened society propagating the significance of universal education, vocational training, public health care, social fairness, good governance, international peacemaking etc. This will ultimately be an inception of human betterment. Collony (2013) further asserts, "He is seen as the beginner of potential of Quakerism with regard to influencing the common good of the human prospect"(p.1). The revelation of right relationship among different ethnic groups permeates the entire ethical horizon of spiritual development which would evoke the sense of equilibrium and plead for peaceful existence.

\section{DISCUSSION AND RESULTS}

\section{The Road to Elephant Pass an Outcome of Ethnic Conflict}

In most of the ethnic conflicts, the issues related to identity would be basic source of resentment and aggression which would be propagated by various political and economic discriminations. Sri Lanka, a religiously and ethnically heterogeneous land once faced dangerously lethal identity crisis after it was declared free from the British colonization in 1948. The minority Tamils living under discriminatory laws imposed by Sinhalese majority were badly treated in the terms of political and economic resources for many years. This maladjustment led the Tamils to raise the weapons in the guise of the extremist group, the Liberation of Tigers Tamil Elam (LTTE) demanding full autonomous in the forms of secession. Elucidating the consequences of the conflict, Bandarage (2009) writes, 
The armed struggle between the Sri Lankan government and the secessionist LTTE (Liberation Tigers of Tamil Elam, also known as the Tamil Tigers) has turned Sri Lanka into 'one of the most dangerous places on earth'. A vicious territorial struggle has been going on in the northern and eastern regions, while the entire island is threatened by suicide bombings and other deadly attacks. Since 1983, 70,000 people - the majority of them Tamil, Sinhalese and Muslims civilians - have been killed due to the conflict.(p.1).

The conflict continued for more than thirty year causing death to the lives of thousands of Sri Lankan people including some Sri Lankan Prime Ministers and other important leaders. Delineating root causes of Sri Lankan conflict, Mushtaq (2012) explains, "Identity is one of several fundamental human needs that underlie many intractable conflicts. Identity is the primary issue in most racial and ethnic conflicts"(p.202). Illuminating this issue, many Sri Lankan writers like Shyam Selvadurai, A. Sivanandan, Punyakante Wijenaike, C. Suriyakiranan, Arthur De Zoysa, Nihal De Silva etc. have written some good novels like Funny Boy, When Memory Dies, An Enemy Within, Kilali Crossing, No Longer My Child, The Road from Elephant Pass etc. about the ongoing conflict. Nihal De Silva's The Road from Elephant Pass written on the background of Sri Lankan civil war between Sinhalese and Tamils which the world knows as ethnic conflict has brought out how the issue related to ethnic conflict has been handled in the fiction. Concerning this novel with the possibility of reconciliation and harmony Jeevahan (2014) elucidates;

The literature produced after the late 1970s mainly depicted the outcome of the civil war and the ethnic conflict. The main aim of this novel was to bring out how the issue of ethnic conflict has been handled in this fiction. The novel can be analyzed how by developing mutual understanding among communities all the barriers like race and ethnicity could be wiped out. This novel has also highlighted how both Wasantha and Kamala, the main characters were reformed after developing love and mutual understanding in them and has portrayed that similar reformations within the communities could create ethnic harmony.(p.414).

\section{The Road from Elephant Pass: a Search for Peace}

The over-arching perspective on Quaker peacebuilding approach has been transformative theme to constructive harmonious relationship 
that can be fitted strongly with the sustainable peacebuilding literature. In contrast to the traditional Western-centric peacebuilding paradigm, Collony (2013) argues, "the four Quakers' approaches - truth, equality, peace and solidarity to peacebuilding put social reconstruction to the fore, embracing universal humanitarian ideals" (p.ii). Such outcomes illustrate the peacebuilding processes of a lesser-known non-proselytizing religious movement - the Quakers - whose tradition is rooted in personal, social and political transformation. It contributes to the mounting body of evidence that religious actors, given certain constraints, have the potential to contribute towards the constructive and peaceful resolution of conflict. With this view, it is important to notice that one should not be confused with human betterment with the idea of progress. It has generally been seen as the continual availability of an increasing diversity of consumer goods, the pursuit of ever increasing convenience, and the attainment of ever-higher levels of personal care and security. And now one must add, instantly available and continuous entertainment as an emerging category in this utopian dream world that is consuming the planet.

The Road From Elephant Pass written in 2003 was awarded the Gratiaen prize and the State Literary Award for the best Sri Lankan Literary work in English for 2003. The Gratiaen Trust was set up on the initiative of Michael Ondaaje after his book, The English Patient which was awarded the Booker Prize (Jeevahan, 2014, p. 412) The novel opens with Wasantha, the Sinhalese army captain waiting for the woman LTTE activist Kamala Velaithan who has turned against them. The opening scene is set in Elephant Pass, a key place in the battlefield which controlled the Wanni (an area under control of the LTTE) and the Jaffna peninsula. The first meeting of Wasantha and Kamala was not a pleasant one for both of them. The beginning itself shows clearly how the novelist has brought out the central issue - the ethnic conflict, a crucial problem and a lack of mutual understanding and peace in the country.

The Sinhalese captain Wasanta's task is to take the rebel, Kamala to Jaffna and from there to Colombo and hand her over to the army headquarters there. The vehicle in which they were travelling comes under attack and Piyasena, the driver and the woman soldier who accompanied them are killed on the spot. Wasantha and Kamala escape fortunately. Without the vehicle both Wasantha and Kamala takes various modes of transport to reach Colombo. During twelve nights they have to spend all their time together talking on various issues including the central issue. Both talk how 
Sinhala army and Tamil rebels destroy each others' physical property and take lives as many as possible.

But as the time gets on, they, having criticized each others' people's actions commence understanding the compulsions of both sides that all people in their groups are not vicious. What the novel suggests is that, only through repenting for what has been done and pardoning for what has happened could lead to restore peace and harmony between the communities. This is further emphasized through the words of Kamala: "I'm sorry; captain . . . You say, there's been no violence against Tamils in seventeen years, so it is ok. Forget about the past, you can live here peacefully as long as you behave yourself. .." (de Silva, 2003, p. 154). Later on, the novel foregrounds one important concept that mutual understanding between two ethnic groups could lead to a solution for the conflict and finally war is not a solution to end the problem and to restore peace and harmony in the country. The key point, apart from ethnicity and enmity, what wins at the end is humanity and love which are essential to do away any kinds of discrimination from all warring groups.

The use of the survivor motif, as a means of revealing the protagonists' characters in the novel sounds good. After they have gone through these life-threatening encounters in the jungle, during which they save each other's lives, the two protagonists unwittingly come to understand and care for each other. Reaching across cultural and ethnic boundaries in order to survive, transforming their previous alienation and enmity into intimacy, understanding, and emphasizing the possibility of a renewed amity and peaceful coexistence between the two warring ethnic groups sound pleasant at all. Significantly, the reader is presented with a gallery of images of the male ego depicted in heroic proportions where male supremacy is highly accentuated. Applauding this condition, Arny Aurangasri Hinriksson (2014) writes, "The heroic metaphors create the impression that the Captain, although a military officer, has never slain wantonly or stained his hand in innocent blood but only in self-defence"(p.157). Violence in respect to chivalry among men is a traditional gender marker and this is demonstrated by the Captain killing the attempted rapist to save Kamala. This attempt the captain has done to save Kamala's dignity unfolds the possibility of unification and pacification of the rivalries. Even here, he is neither presented as a ruthless soldier crushed in spirit by the brutal regimentation of military life, nor to be embittered by the deception, hypocrisy and cruelty one finds in pursuit of war aims. The feeling of love and pacifying emotions 
have sued in him. In the eagerness to use masculine imagery, the author has further "imbued the Captain with virtues close to Western ideals of masculinity" (p.157). That ultimately rescues both to cohabit the struggling path together.

Gradually hatred and misunderstanding between them corrodes away and mutual understanding and love evolves. It is clear when Wasantha says, "She started giggling. It spoiled the whole mood but I think that was when the barriers between us finally came down" (de Silva, 2003, p.348). The key message is reformation within the rival communities which will lead for a solution to ethnic conflict and end all the hatred and misunderstandings. The dialogue spoken by Wasantha better clarifies this;

How many thousands of my countrymen and their children, parents and lovers taken in for questioning in the same way? How many real people, each loved and cherished by someone, had been taken away to be broken and brutalized? And all in the name of security! How many victims had found it useless to scream out the truth because no one believed them till they had been taken to the unbearable limit of pain? (p. 410)

The novelist has been successful in bringing out the fact that love and compassion can solve the lost lasting problems prevailed in the warring communities. Towards the end of the novel, when both meet at the headquarter their conversation clearly shows the concern towards each other and pain of separation in their mind.

"You worried about me didn’t you?"

"Yes.... I wouldn't want to live through the last two days again."

"I am so sorry Wasu......... I have caused you so much pain and it was all my

fault.

“That's all in the past. I'm just happy you are all right." (p.423)

When Wasantha told her that he had to go back to Elephant Pass and had to join the troops there, the reply of Kamala, "Please Wasu, please take care! Don't try to be a hero. Just come out of there alive" (p.424), reveals her love and concern for him. In the end both of them were confronted with 
the feeling of separation and were thinking whether there would be any possibility of a future life together.

In the beginning while presenting the first physical release of their love, both seem to have brave illusions about each other, especially as the character of the Captain has been established as that of a chivalric soldier and Kamala as an antagonistic force to him. Explaining their pathos and duality, Hinriksson (2014) further elaborates, "Although he has played the part of a heroic protector during the most part of the journey, they do not take a vow of eternal fidelity nor give the impression that a vital marriage is imminent or even possible"(p.160). The transformation of confusion and pertaining pacification in them is seen when this final joining of body and soul is depicted as "an erasure of earlier discord, stemming from ethnic prejudices, and finally as a kind of epiphany"(p.160). Gradually, once the emotional height of the moment has worn off after their brief sexual encounter, Kamala's safety and welfare again become the Captain's prime concerns. The Captain's concern also reinforces his own gratifying role as the protector, and thus a subtle finesse is accorded to his character. He knows that her situation as a traitor of her leader and a deserter of the movement is potentially dangerous: "The Tigers would summarily execute any villager suspected of collaborating with government troops" (de Silva, 2003, p. 419). She is also presented as cognizant of the risks and the repercussions that her actions would invariably entail some positive outcomes. As their friendship gets stronger, they learn to trust each other and discuss their family backgrounds, their personal past and their ambitions for the future. She too becomes "concerned about the dangers that he will face while fighting the terrorists in the North" (Hinriksson, 2014, p. 160). One can easily anticipate the proximity the rivals are pertaining despite the outgoing horrendous situations.

While looking into the essence of the plot, de Silva is seen unrelentingly in pursuit of an elusive future in a predominantly violent landscape eyeing on the possibility of pacification of enmity. In doing so, "he moves us increasingly to the dangerous realms - on to the unknown - to an unpredictable terrain where no assumptions are possible"(p.157). The mental and emotional state of the main characters which would only expect lethal consequences gradually aligns with positive ones, due to 
the common, savagely threatening circumstances that they face together in the unfamiliar surroundings of the forest Park. Sometimes, villainous circumstances would be supporting and enhancing to the sufferers. In this condition, the protagonists are pitted in conflict against wild animals and renegade soldiers hiding in the Park, and not against each other, which gradually put them closer. The full arresting imagery narrative of an attacking sloth bear, an encounter with a leopard and a herd of charging, wild buffaloes is helping in looping up the incidents all together. During their risk-laden trek, Hinriksson (2014) further states, "Kamala saves the Captain's life by alerting him to the close presence of a lone and enraged rogue elephant"(p.157). There is increasing physical intimacy when they snatch each other from imminent harm, that leads them to further closeness. Thus, a significant sexual symbolism with the wilderness context of the novel is established to weave out one possibility of love, pacification and intimacy among the rival groups and people living in such communities can live peacefully hereafter.

The most important scenario the novel unfolds in the end is that resolution of conflict and reconciliation of differences which are feasible through mutual experience and regard to each other as per the principal motto of Quakerism. Otherwise it all seems implausible. Apart from racial differences and enmity, what stands out in the story is humanity, pacification and love, the ultimate goal of all creeds. The enmity and ethnic difference disappear gradually in both Wasantha and Kamala and finally they become reformed characters, a meme to those who still strive to live in turmoil. On one level the novel deals with the theme of ethnic conflict and its impact on both the Sinhala and Tamil communities, but on the other hand it elaborates enormous possibility of peace and love among the rival groups who would be fighting for a long time in history. The novel vividly portrays the attitude of both communities regarding this issue and highlights their view and their stand on this issue, the essence of peace in revolution. Besides, the novel entails that mutual understanding between these communities could lead to a permanent solution for the ongoing ethnic conflict and ultimately killing each other is not a solution to terminate the ethnic conflict and to restore peace in the country. 


\section{CONCLUSION}

In a nutshell, the main purpose of this article is to bring out how the issue of ethnic conflict has been solved with the spread of love and peace - the essence of Quakerism which chills the hot. The novel unfolds one great possibility that only mutual understanding and pacifying motif among the rival communities can pave way for the ultimate ethnic harmony. The hatred and enmity will only lead to conflicts and become a crucial factor for division. The article has discussed how reformation took place between Captain Wasantha and rebel Kamala during the course of their journey and reveals that to prevail ethnic peace and harmony the same reformation should take place within communities. For those who always eye bad in good the unbiased and balanced nature of the novel is an eye-opener and an appropriate and a valuable contribution towards the process of building bridges between the two dissenting communities for pacification of anger and hatred. Despite the fact that Wasantha is Sinhalese, he sees the attitudes of the majority of Sri Lanka as responsible for the sectarian violence that has spread across the country during the last decades. It is evident that his liberal judgment in characterization and chosen situations is delivered from a cultivated moral standpoint. Above all, the novel conveys the message that truth, reconciliation, equilibrium and pacification as well as resolution of the long standing conflict are ambivalent through mutual understanding, communal collaboration, trust, love, compassion and above all peaceful reconciliation.

\section{REFERENCES}

Bandarage, A. (2009). The separatist conflict in Sri Lanka terrorism, ethnicity, political economy. New York: Routledge.

Boulding, K. E. (2002). The evolutionary potential of Quakerism. Pennsylvania: Pendle Hill Publications.

Connolly, P. (2013). Building relationships: Quaker peacebuilding in a Pacific context. An unpublished Master's Diss. Dunedin: U of Otago.

De Silva, N. (2003).The road from elephant pass. Colombo: Vijitha Yapa.

Helmuth, K. (2009). The evolutionary potential of Quakerism. Revisited from Kenneth Boulding to John Bellers. Quaker Studies. 2(3), 3763. 
Hinriksson, A. A. (2014). Dissident voices sociocultural transformations in Sri Lankan post-independence novels in English. An unpublished Ph.D. Diss. U of Iceland.

Islam, Md. T. (2013). Peace and conflict studies: Evolution of an academic discipline. Journal of the Asiatic Society of Bangladesh. 58(1),129155.

Jeevahan, T. (2014). Mutual understanding and ethnic harmony in The Road from Elephant Pass. Research Journal of English Language and Literature (RJELAL). 2(3), 414-421.

Mushtaq, S. (2012). Identity conflict in Sri Lanka: A case of Tamil Tigers. International Journal of Humanities and Social Science. 1. 2(15), 202-210. 